\title{
In Memory of Joanna Renc-Roe
}

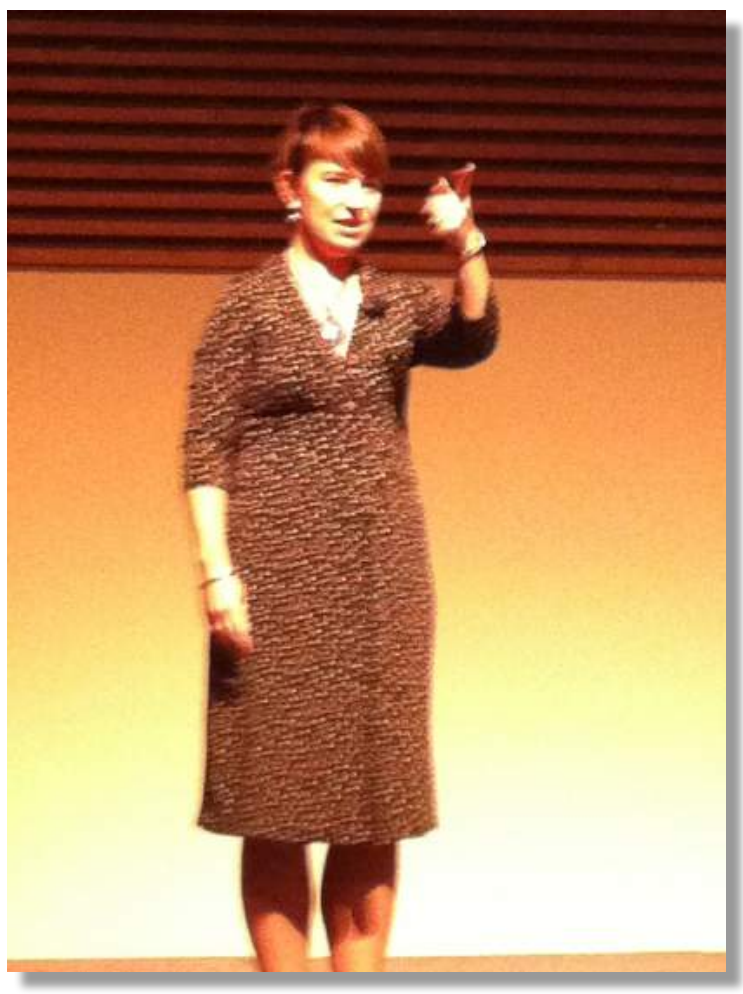

Our colleague Joanna Renc-Roe has left us, much too early. ${ }^{1}$ It is with great sadness we write these words, but also with warm memories and gratitude for having known Joanna, her work, and her contributions to the world of SoTL. Joanna worked at the Center for Teaching and Learning at the Central European University in Budapest, Hungary. Her academic interests concerned professional development, internationalisation, and the relation between policy and practice in higher education. She was member of the editorial board of Teaching \& Learning Inquiry, and a regular attendee at the ISSOTL-conferences.

We particularly remember and appreciate that in her ISSOTL12 keynote in Hamilton, Canada, she problematized the fact that scholarship of teaching and learning does not translate into most European languages-a matter of fact that we continuously need to bear in mind. She was an important team member in initiating and planning the first Euro-SoTL Conference in Cork, Ireland, in 2015. She had served for over 5 years as an external advisor for the Irish National Academy for the Integration of Research, Teaching, and Learning, and before that as a valued member of the CASTL Campus initiative on Graduate Education.

Joanna was a very intelligent, warm, generous, and humorous person. She had lots of energy and was always great to have conversations with, about life in general and academic life in particular. We envision her now sitting at the waterfront at Malta, where she loved spending time, enjoying the lemon trees and the sunshine. We will miss her deeply.

Katarina Mårtensson and Torgny Roxå are academic developers, at Lund University, Sweden, and Bettie Higgs is Senior Fellow, Teaching and Learning, at University College Cork, Ireland. Joanna was engaged in collaboration with all three in both institutions. They are also engaged in ISSOTL, the International Society for the Scholarship of Teaching and Learning, where Joanna participated and actively contributed over many years.

NOTE

1. This tribute originally appeared on the ISSOTL blog on April 26, 2016. 
Copyright for the content of articles published in Teaching \& Learning Inquiry resides with the authors, and copyright for the publication layout resides with the journal. These copyright holders have agreed that this article should be available on open access under a Creative Commons Attribution License 4.0 International (https://creativecommons.org/licenses/by/4.0). The only constraint on reproduction and distribution, and the only role for copyright in this domain, should be to give authors control over the integrity of their work and the right to be properly acknowledged and cited, and to cite Teaching \& Learning Inquiry as the original place of publication. Readers are free to share these materials-as long as appropriate credit is given, a link to the license is provided, and any changes are indicated. 